\title{
The Neoliberal Stamp on Post-socialist Art ${ }^{2}$
}

Abstract: The main objective of this paper is to provide an outline for a future theorisation of the following question: what is it that specifically determines the art of our time, that is, how do the conditions in which this art is created differ from the conditions in which art was created a decade or even twenty years ago? In order to carry out this analysis, it is necessary to take into account several factors: (a) the specificity of the social order within which the art of our time is created, that is, the evolution of a neoliberal "transition" state and its ideological apparatus; (b) the problem of material work forms, which has to do with economic production models that both contemporary neoliberal state and art are based upon; (c) the issue of value (for want of a better word let us call it "aesthetic") which is implied or entailed by the work in the field of art.

Keywords: art, transition, post-socialism, society

UDK: 7:316.323.6

\section{Neoliberalni pečat postsocialistične umetnosti}

Izvleček: Glavni cilj tega prispevka je ponuditi osnovo za prihodnje teoretiziranje o naslednjem vprašanju: kaj je tisto, kar specifično določa umetnost našega časa, torej kako se pogoji, v katerih ta umet-

\footnotetext{
${ }^{1}$ Nikola Dedić is Associate Professor at the Faculty of Music, Belgrade, Serbia. E-mail: dedicnikola@yahoo.com.

${ }^{2}$ An early version of this paper, titled "Art in Peripheral Capitalism", is published in the exhibition catalogue of the $17^{\text {th }}$ Biennale of Arts in Pančevo, See Art Gates (2016), Kulturni centar, Pančevo, 63-85.
} 
nost nastaja, razlikujejo od pogojev, v katerih je nastajala umetnost pred desetletjem ali celo dvema? Če želimo izvesti to analizo, je nujno vračunati več dejavnikov: (a) specifičnost družbenega reda, znotraj katerega nastaja umetnost našega časa, torej evolucijo neoliberalnega stanja "tranzicije" in njenega ideološkega aparata; (b) problem oblik materialnega dela, ki je povezano z ekonomskimi proizvodnimi modeli, na katerih sta osnovana tako sodobno neoliberalno stanje kot umetnost; (c) vprašanje vrednosti (v iskanju primernejšega izraza mu za zdaj recimo "estetske"), ki se implicira ali narekuje z delom na področju umetnosti.

Ključne besede: umetnost, tranzicija, postsocializem, družba

\section{* * *}

The dominant ideological meta-narrative within which post-socialist societies developed after the fall of the Berlin Wall and the collapse of the communist project was one of a "democratic transition" and a new state of liberal democracy. A constituent of this narrative is the story of "totalitarianism": former communist societies should overcome their totalitarian legacy and enter a society of liberal freedom, human rights, democratic distribution of power and, of course, free market. Thus the EU becomes the ultimate goal of historical development, and the European integration process becomes the path to be followed by former totalitarian societies in order to transform, gain an education, and mature, with a view to turning from non-European dictatorships into European democracies. However, as the historian János Kornai shows on the example of his homeland Hungary, the idea of liberal democracy, especially in the aftermath of the great economic crisis in 2008 , has reached its definitive debacle, even ceasing to play the role of 
an ideological meta-narrative. ${ }^{3}$ Kornai analyses institutional, legislative and ideological changes brought on by Orban's regime: one of the founding principles of liberal democracy, the separation of executive and legislative powers (a separation that has probably never been achieved in Eastern European countries but has at least functioned as an attainable "ideal"), was suspended with a series of legislative changes. These included changes to the constitution, electoral laws, media laws, election of state prosecutors, etc., which culminated in the passing of the so-called 32 "cardinal laws", whose further potential change can be implemented only with a twothirds majority in the parliament. In terms of economy, Orban's Hungary abandons the market model and heads for state protectionism; this does not mean turning back to the socialist model but to a new form of neoliberal economy. The latter replaces a nominally free market with a clientelist system where economy develops under the fundamental influence of political elites close to the Prime Minister. Finally, there is strict control of the "cultural sphere", which started with a radical "purge" of the media and which leads to the institutionally shaped negation of any ideological "pluralism". Kornai's thesis is that these changes are structural, that is to say, they do not constitute a deviation, degeneration, or dysfunction of a liberal system, but build a new system that cannot even theoretically be called liberal.

Nor can this new system be called a "dictatorship" in the traditional sense of the word. In fact, it is a sort of hybrid between "liberal democracy" and "dictatorship", which, for want of a better word, Kornai refers to as autocracy. This transformation from democracy (at least in principle) towards autocracy is, owing to a series of legislative and institutional changes, practically irreversible:

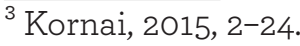


Fidesz is prepared for the unlikely but not impossible event of its failing to win a parliamentary majority in the next elections. The 32 cardinal laws can only be modified by a two thirds parliamentary majority, and even in the case of Fidesz' electoral defeat no such majority would be possible without their participation. The mandates of many key positions, most importantly those of the chief prosecutor, president of the republic, head of the central bank, of the audit office, and of the judicial office, extend beyond the current parliamentary cycle; they can sit tight, even if the opposition wins. The fiscal council, a body appointed by the present government, but which would remain in office even in case of an election defeat, has not only an advisory role but also the right of veto over the budget submitted by a new government. If that veto is used, the president of the republic may dissolve the parliament and call for new elections. In other words, a few hand-picked men loyal to the present government would be able to overturn the next government.

All of this leads to the logical conclusion that it would probably be extremely difficult to effectively dismiss the government at parliamentary elections. In this sense, the situation that has emerged is nearly irreversible. Historical experience shows that an autocracy can only be brought down by an "earthquake" that rocks the very foundations of the system. ${ }^{4}$

Although he writes about Hungary, Kornai's thesis is gaining confirmation in other countries as well, both in the former socialist bloc and the countries of the so-called peripheral capitalism. The paradigmatic place is actually Putin's Russia, but states such as Erdogan's Turkey, Poland, and former Yugoslav countries are going

${ }^{4}$ Ibid. 
through substantially similar processes. This does not necessarily mean that "Putinism" is the model, or a role-model for the processes of a new neoliberal autocracy constitution - all these countries experience the erosion of liberal democracy meta-narratives in specific local circumstances and traditions, and within different networks of international economic and political relations. However, what still links them to each other is a strong neoliberal economic policy, which is necessarily clientelist. On the one hand it implies strong social and class stratification, and on the other the strengthening of conservative elements in the ideological sphere domain, which is in some cases (as is the case with the latest Croatian government or the process of rehabilitation of the Second World War collaborators in Serbia and elsewhere) openly neo-fascist. A more detailed research into the extent to which these processes have become irreversible in post-Yugoslav countries is beyond the scope of this text: direct parallels between Serbia and Hungary still cannot be drawn because Serbia has not yet implemented the structural constitutional and legislative transformations of the political system that would be reflected in an even more rigid constitution and change of electoral laws, although there have been sporadic announcements of the sort. The revision of private property still has not been carried out, nor its "amendments" through a state centralised economy. On the other hand, similarities are obvious - the concentration of power in one political personality, clientelism, suspension of power distribution, elimination of a functional opposition, changes in labour legislation, and perhaps most notably full control of the media, that is, "ideological apparatus". Kornai's thesis points out precisely the fact that the process marked as "democratic transition" has finally been rounded off, which means that former socialist countries have entered a new "post-transition" phase of their development. The question that arises is how this gradual formation of an autocratic 
neoliberal country of peripheral capitalism is reflected in the field of art and artistic production.

The socialist system viewed art in a broader context of modernism as a universal meta-narrative. In this regard, communist systems, including the Yugoslav system, saw art as the key place of political self-legitimation: socialism "with a human face" is only possible as part of the global emancipatory meta-narrative. Thus a communist state treats art within a kind of Hegelian teleology: the totality (the universal) is achieved by the interaction of a multitude of opposing subtotalities (local modernisms), not annulling but integrating them into this "higher" form of totality (the universal concept of "great" modernism). Disintegration of the teleological art narrative happened parallel with the disintegration of the socialist project: after the fall of the Berlin Wall (if not even earlier) it was hardly possible to speak of a universal project of modern art. From the state of modernity, art has come to the state of contemporaneity, that is to say, it has become a series of synchronic micronarratives, none of which reaches the level of the Hegelian totality. Yet it would be wrong to assume that the "transitional" state rejects all forms of artistic teleology: the logic of liberal transition is basically teleological. Serbian Prime Minister Zoran Đinđić once said: “Our generation is a generation that has a huge responsibility. Of course, with responsibility comes great honour. We have been chosen, we have a mission to complete." This mission, of course, is the European Union. Within such logic, history is seen as a teleological narrative that leads to the ultimate self-fulfilment: the order of liberal Europe is a kind of "homecoming", the end of history, which can be reached only through rejection and complete erasure of the $\mathrm{Yu}$ goslav socialist legacy. Art resumes its place within this liberal-capitalist teleology: the concept of "Eastern European art" is the construct included in the project of cultivation, "civilisation", of 
local pre-modern societies into the community of European democratic nations. As Miklavž Komelj states, "Eastern" art is those postconceptual practices that reflect on avant-garde heritage (perestroika art, soc-art, Yugoslav retro-avant-garde). The constitutive element of this art is a myth of the socialist "totalitarianism", underlined by the broader historical process of restoring capitalism, and therefore the global art market as well. In Komelj's words:

The rhetoric of "Eastern art" refers to the otherness of the "East" and the subversion of that otherness in the global art system which we could understand exactly as fighting against the ideological disqualification of the "East" performed by the "West" through the use of the term "totalitarianism" [...]. This thesis, however, is nothing more than a way to incorporate the "East" as such in the space of the "West", that is, a globalised art market now. Thus, of course, the "East" becomes harmless; something that until recently represented a real threat to the "West" becomes a potential cultural wealth that can fill the globalised art system with new vitality. It is about how to convert social issues into issues of art and launch them as such onto the globalised art market. ${ }^{5}$

This process of capitalist culturalisation of the "East" meant at the same time the construction of an entire institutional infrastructure of "Eastern" art production: the paradigmatic place is the launching of the Soros Centers for Contemporary Art network (SCCA), and then large biennial exhibitions such as Manifesta. The real break-up of this artistic teleology occurred only with the completion of the transition: only a neoliberal "post-transition" state does not truly need contemporary art as a source of self-legitima-

\footnotetext{
${ }^{5}$ Komelj, 2011, 32-33, 185-201.
} 
tion. The dominant narrative of the "post-transition" cultural logic is no longer that of a more democratic integration but one of pure market, which is supplemented by the ideological rhetoric of "austerity" and by phasing out a large part of what we once perceived as the "public sector". Parallel to this, there occurred a disintegration of cultural infrastructure, both the infrastructure that was built in socialism and the one that was made up of "independent" cultural and activist organisations (NGOs), such as the aforementioned Soros network of Centers for Contemporary Art. That is why the protagonists on the contemporary art scene in countries like Serbia feel as para-institutional workers. This feeling is followed by a disorientation in both conceptual and, even more so, institutional sense, as well as by the feeling that a post-transition state recognises only "occasional" culture (e.g. popular music festivals and similar commercially viable "entertainment" events) but not the supposedly "serious" culture, such as contemporary art. In other words, "post-transition" art is art which does occur within the neoliberal framework, but is devoid of the "transitional" teleology of reaching liberal democracy.

Working in the arts also reflects well the transformation of work caused by integration into the neoliberal market, which can be described by the standard term of precarisation. The precarisation of art is the result of both external factors (global transition from Fordist to post-Fordist production model) and the development inherent in art as such. The art historian and curator Jelena Vesić advances a thesis according to which the concept of contemporaneity was introduced in art and aesthetic debates precisely through the construct of post-socialist transition (and thus "Eastern European" art as well), which brought with it the "managerial" model in terms of institutional infrastructure for the production art: the basic premise was that the culture of Eastern countries was "contaminated" 
with "totalitarian" ideology and state control (concern), and that the main task of today's historians, curators, or artists was the "opening" of contemporaneity, which was to be achieved through a "renovation", "reconstruction" and "new management" of history. Hence, SCCA offices have become the new meeting places of artists, but now these places are run by hired managers (usually local art historians and critics). While in the socialist system the development of art was decided upon by the state, the development of contemporary art depends on the decisions of a few expert councils (modelled on company management in the West). In this regard, "post-socialist art exhibitions in most cases are not judged, but curated - they are now curated either by a 'council' or, in later stages, by an invited curator" ${ }^{6}$ Moreover, while modernist authors focused on the métier (artistic skills), creating tangible artefacts/works in their studios, the author in post-Fordist neoliberal economy conditions spends most of his time in offices "engaging in post-studio practices, dealing with communication, documentation, creating projects for his/her future works, researching, planning and so on". 7 It is about constructing a new type of artist-entrepreneur who no longer requires art institutions as institutions of social care but works on the curator-manager model, or as Vesić points out, as a self-governing individual who solves "his/her existential issues either on the art market (still linked to objects) or in the context of the project market". ${ }^{8}$ This (neoliberal) paradigm, first established within the SCCA network, remains a model to this day.

"Post-transition" art is thus created in conditions of the complete dismantling and disintegration of institutional frameworks that were

\footnotetext{
${ }^{6}$ Vesić, 2015, 68.

${ }^{7}$ Ibid.

${ }^{8}$ Ibid.
} 
initially formed in the socialist era, but it is left without even "alternative" institutional frameworks, which were once provided by the ideology of "liberal" integration of post-socialist societies and its inherent concept of "Eastern European art". The precarious market model is the dominant framework of today's art. However, at this point there emerges a paradox which is also characteristic of global frameworks: although it offers work in precarious conditions, often unpaid work, social insecurity, etc., the number of art students is not declining. The last decade saw the introduction of private higher education in Serbia, and one of the trends is an increase (not decrease, as might have been expected) in the number of art academies, departments of new media, digital art, art theory, curatorial practice, design and so on. This is one of the paradoxes that point to the fact that work in the field of art, even in precarious neoliberal conditions, carries a specific type of symbolic value, a kind of "symbolic capital". The question remains how to consider this kind of cultural value which is implied by the work in the field of art. It seems that in the local circumstances at least three dominant discourses can be identified: (a) traditional; (b) market (or entrepreneurial); and (c) the discourse of contemporary art in a strict sense (this is, of course, only an approximate and intuitive typology).

The traditional model refers to mostly common-sense guidelines within which a work of art is treated as an autonomous "beautiful" object in an indifferent and non-utilitarian sense. An autonomous work is an "outstanding" object, rarely a situation or event, which essentially means masterfully made, authentic or unique. "This kind of "common-sense" definition of art occurs in different contexts, and is often an argument within the institutional realignment on the local art scene - a good example is the change

$\overline{9}$ Šuvaković, 2010, 408-411. 
of the Management Board and program of the October Salon, where objections to the current concept, mainly articulated within official art associations, rested on the argument that the Salon had stopped dealing with "beautiful" art, authentic aesthetic values and visual arts, that "waste" was exhibited instead of genuinely valuable works (according to one of the critics of the "conceptual" approach to contemporary art), and that international artists had been privileged at the expense of local, national authors. On the other hand, the traditional approach is also characteristic of a phenomenon typical of the new millennium since its beginning: the emergence of private collectors who are mainly governed by the logic rooted deeply in the "object market", preferring art based on the idea of "artistic" and aesthetically valuable art objects. Nevertheless, this "traditional" value model often spreads beyond the scope of guild artistic circles into the broader field of political debates and realignments: from conservative and right-wing advocacy for an "authentic" national culture to, for example, debates on reality television programs, where the mass media aesthetics of "kitsch" are supposedly countered by "authentic" high culture and art. An example is last year's protest by a student organisation, "Sistem vrednosti", which supported a petition against reality programs by playing classical music concerts in the central city square; as the mainstream media reported, "they say that they want museums and theatres, rather than 'Farms', 'Couples' or 'Big Brother', and as they stated, they showed that they appreciated real Serbian and European culture, and were against the promotion of immorality and stupidity, which abound in TV programs".

Another model that we have singled out is the "market" or "entrepreneurial" model. It is a context gradually built by creative industries: in circumstances where the state withdraws from everything that was once understood as "public goods", including artistic pro- 
duction, a market environment is supposed to emerge that will enable economic "self-sustainable" cultural policies. One of the ways that should allegedly make this possible is through the so-called public-private partnerships. The basis of this is the affirmation of private enterprise, which is based on the combination of art, social activism, marketing, and collaboration between people working in the field of art and private companies. One of the implicit arguments of this view is that there is still no "real" market in our country and that our cultural scene is branded by bad habits from the socialist era, rooted in the state's patronising attitude towards culture, as well as by the lack of a "global trends" knowledge, successful management, and ideas. The naivety of these views aside, if the market did not solve any of the transition society problems, why should we expect it to resolve cultural production issues? It is of much more importance to realise that the "free market" concept is one of the constituent ideological constructs of transition countries: as indicated by Kornai in the abovementioned text, peripheral capitalism rests on a centralised, clientelist system in which the state functions as the prime regulator of the market. The curator Vida Knežević has written most strikingly on this issue, analysing the work of an event based on the concept of "public-private partnership", noting that creative industry work actually means state controlled and patronised business modelled by local private companies, "whose business is largely non-transparent, and rests on privatisation of social property, social infrastructure and resources built during the period after the Second World War"..$^{10}$ In her opinion, it is a complex mechanism of institutional collusion between private business, political elites in power and the new managerial class, which actually masks the structural conflict between work and capital.

${ }^{10}$ Knežević, 2016. 
Finally, the third model is the contemporary art discourse in the narrow sense of the word. It suggests diverse post-post-avant-garde and postconceptual practices, which have generally rejected dealing with traditional art objects. What they start from is art as a form of political practice rather than its aesthetic "content". The institutional framework of this art is based on the networking of local practices with international art "worlds", where the underlying form is the concept of international biennials and the increasingly frequent art fairs. These practices are often positioned as critical, even subversive in relation to the local ideological, political, aesthetic and economic models. With reference to this, as indicated by the French sociologist Nathalie Heinich, the main axiological determinant, a kind of pre-condition for the integration of such a work into the globalised contemporary art system, is transgression. ${ }^{11}$ In the modernist model, mediation between the work and the recipient tended to be direct and unmediated (and where the artist's main task was expression, the rendition of his private world). Today, by contrast, in order to enter the art system, a work of art has to question and even go beyond the borders of what is rationally considered a work of art. Artists create ambivalent, "transgressive" works and the mechanism of their "socialisation" is achieved through a curator and theory respectively. This is what Heinich calls the "permissive paradox" of the contemporary art system:

We cannot understand how contemporary art functions unless we understand that, while artists are trying to push the boundaries, mediators (intermediaries) simultaneously keep extending the borders so that artists can get in - while at the same time the incompetent keep crying "but it is not art". This is what I

\footnotetext{
${ }^{11}$ Special thanks for the comments on the transgression thesis and referral to Nathalie Heinich's text are due to Dr. Rade Pantić.
} 
have called in the conclusion of my book the "permissive paradox", which refers to the fact that by accepting and integrating transgressive proposals, contemporary art institutions are acting in a way contrary to what artists they supposedly support are doing because they pre-accept everything that is created as opposed to their power. ${ }^{12}$

This is precisely the mechanism by which "Eastern art" was created: authors create an ideologically and politically ambivalent, that is, provocative and subversive work, and the mediation process is carried out by specialised experts - critics, theorists, curators. A typical example of this is the famous Irwin group and the NSK (Neue Slowenische Kunst) movement intervention, remembered in the history of art as the "poster scandal", which rested on an ambivalent attitude to the thesis of "totalitarianism"; Irwin's international success lies in the impossibility of any "straight-line" reading of their work either as a glorification of totalitarian ideology or as its criticism and deconstruction. Local contemporary art scenes in former socialist countries are marked by the influence of such a "mediation" mechanism, which is the basis of the global art system: local art is often marked by internal tensions - "short circuits". These mainly revolve around the question which artistic gesture is "authentically" political and which reflects "backward", "bourgeois", "nationalist", "conservative" ideologies, etc. It is indirectly expected that "progressiveness" will ensure a work's integration into the globalised art system. Another typical example of this kind was a major debate about the work Gipsies and Dogs by the artist Zoran Todorović in 2009-2010. Due to its ambivalent character, that is, its resistance to being straightforwardly read either as a critical documentation of racial exploita-

$\overline{{ }^{12} \text { Heinich, } 2007 .}$ 
tion or as its racist reproduction, the work caused a stir and an institutional and ideological realignment of the scene.

We have already pointed out that a common argument in the local art circles is the lack of a "real" market. It is argued that the formation of a functional art market would solve some of the structural problems of contemporary art production and reception. However, we hope that it is clear from the above why this faith in the market is at least ideologically naive: the point is exactly that the art created in post-socialist countries is already part of the capitalist market, that it has already been co-opted by neoliberal logic, no matter whether it is circulating within traditional or contemporary models; the point is that this market is of a peripheral type. This does not mean that it is structurally not integrated into the mechanisms of the global capitalist system, be it the "object market", where private collectors are replacing former public institutions, the market of precarious work, which is taken up by increasingly clientelist-oriented creative industries, or the "project market", where survival in the world of art means integration into a global network of art biennials, residences, etc. Until concrete political answers are articulated, answers which will use a new mass political movement to question the very foundations of the current capitalist system, we can hardly expect art to escape co-optation into the neoliberal order.

\section{Bibliography}

HEINICH, N. (2007): "Soumission - Transgression" ("Submission - Transgression"), Presentation from the Conference at the Centre du Graphisme, December 19, 2006, Institute de la Communication et de Médias d'Échirolles, Université Stendhal Grenoble. KNEŽEVIĆ, V. (2016): "Kvart kulture i njegove kulise" ("Culture Quarter and its Scenery"), http://www.masina.rs/?p=1599. 
KOMELJ, M. (2011): “Uloga oznake 'totalitarizam’ u konstituisanju polja 'istočne umetnosti”" (The Function of the Signifier 'Totalitarianism' in the Constitution of the 'East Art Field'”), Sarajevske sveske, 32-33, 185-201.

KORNAI, J. (2015): "Hungary's U-turn”, Capitalism and Society Vol. 10, Issue 2, Art. 1, 2-24.

ŠUVAKOVIĆ, M. (2010): "Kao zdravorazumska definicija umetničkog dela" ("As a Common-Sense Definition of a Work of Art"), Diskurzivna analiza, Belgrade, Orion Art and the Department of Musicology of the Faculty of Music, 408-411.

VESIĆ, J. (2015): Kustoski gest u svetu savremene umetnosti ("The Curatorial Gesture in the Contemporary Art World"), the doctoral dissertation manuscript, Belgrade, University of Arts, 68. 